\title{
Altererythrobacter dongtanensis sp. nov., isolated from a tidal flat
}

\author{
Zhen-Yu Fan, ${ }^{1}$ Yi-Ping Xiao, ${ }^{1}$ Wei Hui, ${ }^{1,2}$ Guan-Rong Tian, ${ }^{2}$ \\ Jung-Sook Lee, ${ }^{3}$ Keun Chul Lee ${ }^{3}$ and Zhe-Xue Quan ${ }^{1}$
}

Correspondence

Zhe-Xue Quan quanzx@fudan.edu.cn
The genus Altererythrobacter belongs to the family Erythrobacteraceae in the phylum Proteobacteria. It was first proposed by Kwon et al. (2007) and at the time of writing the genus includes seven species: Altererythrobacter epoxidivorans (Kwon et al., 2007), A. luteolus (Kwon et al., 2007), A. indicus (Kumar et al., 2008), A. marinus (Lai et al., 2009), A. marensis (Seo \& Lee, 2010), A. namhicola and A. aestuarii (Park et al., 2011). Members of the genus Altererythrobacter have been isolated from seawater (Seo \& Lee, 2010; Park et al., 2011), marine sediment (Kwon et al., 2007), the rhizosphere of wild rice associated with mangrove (Kumar et al., 2008) and a tidal flat of the Yellow Sea (Yoon et al., 2005).

Strain $\mathrm{JM} 27^{\mathrm{T}}$ was isolated from a tidal flat of Dongtan wetland, Chongming Island, China, by the dilution-plating technique on R2A (Difco) plates supplemented with $1 \%$ $\mathrm{NaCl}$ and solidified with $1.5 \%$ gellan. Gram-staining was performed as described by Gerhardt et al. (1994). Cell morphology was examined by light microscopy (YS-2; Nikon) and transmission electron microscopy (H600;

The GenBank/EMBL/DDBJ accession number for the 16S rRNA gene sequence of strain $\mathrm{JM} 27^{\top}$ is GU166344.
Hitachi) after negative staining with $1 \%(\mathrm{w} / \mathrm{v})$ phosphotungstic acid, using cells grown on R2A agar after 2 days of incubation at $30^{\circ} \mathrm{C}$. Motility was determined by phasecontrast microscopy (Eclipse TS 100; Nikon). Growth at different salt concentrations and $\mathrm{pH}$ was monitored in $\mathrm{R} 2 \mathrm{~A}$ broth incubated for up to 7 days in the presence of 0,1 and $2 \%(\mathrm{w} / \mathrm{v}) \mathrm{NaCl}$ and at $\mathrm{pH} 5.0-11.0$ (intervals of $1.0 \mathrm{pH}$ unit). $\mathrm{pH}$ was adjusted by addition of $1 \mathrm{M} \mathrm{HCl}$ or $1 \mathrm{M}$ $\mathrm{NaOH}$. Growth at different temperatures was monitored on R2A agar incubated for 7 days at 4, 10, 20, 30, 37 and $42{ }^{\circ} \mathrm{C}$. The production of flexirubin-type pigments on R2A agar was determined by using the bathochromic shift test with $20 \%(w / v)$ KOH (Fautz \& Reichenbach, 1980). Catalase activity was determined by bubble production in $3 \%(\mathrm{v} / \mathrm{v})$ hydrogen peroxide solution. Oxidase activity was determined by oxidation of $1 \%(\mathrm{w} / \mathrm{v})$ tetramethyl p-phenylenediamine (Merck). Hydrolysis of starch and Tween 80 , utilization of glucose, fructose, acetate, pyruvate, glutamate, succinate, malate and formate as sole carbon sources, and endospore formation were determined as described by Cowan \& Steel (1993). $\mathrm{H}_{2} \mathrm{~S}$ production was determined on Kligler iron agar (MacFaddin, 1985). Other physiological, biochemical and enzyme activity tests were 
conducted using API 20NE and API ZYM strips (bioMérieux) according to the manufacturer's instructions.

The cultural, physiological and biochemical characteristics of strain $\mathrm{JM} 27^{\mathrm{T}}$ are given in the species description and in Table 1. Strain JM $27^{\mathrm{T}}$ was positive for catalase activity, but negative for hydrolysis of gelatin, $\mathrm{H}_{2} \mathrm{~S}$ production and nitrate reduction; these are common characteristics of the genus Altererythrobacter. The novel strain could be readily differentiated from related species in the genus Altererythrobacter on the basis of several phenotypic properties: it is negative for hydrolysis of Tween 80 , and positive for utilization of fructose and succinate as sole carbon sources.

The 16S rRNA gene of strain JM $27^{\mathrm{T}}$ was amplified by PCR using the universal primer pair $27 \mathrm{~F}$ and $1512 \mathrm{R}$ as described previously (Quan et al., 2005). The typical $16 \mathrm{~S}$ rRNA gene sequences of related taxa were obtained from EzTaxon (Chun et al., 2007) and multiple alignments were performed using the CLUSTAL X program (Thompson et al., 1997). Phylogenetic trees were reconstructed based on the neighbour-joining (Saitou \& Nei, 1987) and maximumparsimony (Swofford, 1993) algorithms using the software package MEGA4 (Tamura et al., 2007) with bootstrap values based on 1000 replications (Felsenstein, 1985). Distance matrices were calculated using the method of Jukes \& Cantor (1969).

The partial 16S rRNA gene sequence of strain JM $27^{\mathrm{T}}$ (1436 bp) was obtained. Strain JM $27^{\mathrm{T}}$ shared highest $16 \mathrm{~S}$ rRNA gene sequence similarities with A. marinus $\mathrm{H} 32^{\mathrm{T}}$ $(96.4 \%)$ and Novosphingobium tardaugens ARI- ${ }^{\mathrm{T}}$ (95.9\%). In the phylogenetic tree (Fig. 1), the isolate was clearly grouped in the genus Altererythrobacter, suggesting that it represents a novel species of the genus Altererythrobacter. Since the highest similarity was lower than $97 \%$, there was no need to perform DNA-DNA hybridization (Stackebrandt \& Goebel, 1994).

Isoprenoid quinones were extracted and analysed as described by Komagata \& Suzuki (1987). For quantitative analysis of the cellular fatty acid composition, $40 \mathrm{mg}$ wet cell material was harvested from Marine 2216 agar (MA; Difco) plates after 3 days of incubation at $30{ }^{\circ} \mathrm{C}$ and the cellular fatty acids were extracted, saponified and methylated according to the protocol of the Sherlock Microbial Identification System (MIDI). The fatty acids were analysed by a gas chromatograph (Hewlett Packard 6890) and identified

Table 1. Phenotypic characteristics of strain $\mathrm{JM} 27^{\top}$ and the type strains of other species in the genera Altererythrobacter and Croceicoccus

Strains: 1, JM27 $7^{\mathrm{T}}$ (data from this study); 2, A. namhicola KYW48 ${ }^{\mathrm{T}}$ (data from Park et al., 2011); 3, A. aestuarii KYW147 ${ }^{\mathrm{T}}$ (Park et al., 2011);

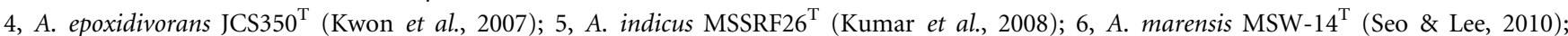
7, A. marinus $\mathrm{H} 32^{\mathrm{T}}$ (Lai et al., 2009); 8, A. luteolus SW-109 ${ }^{\mathrm{T}}$ (Yoon et al., 2005); 9, Croceicoccus marinus E4A9 ${ }^{\mathrm{T}}$ (Xu et al., 2009). All strains were positive for catalase activity and negative for $\mathrm{H}_{2} \mathrm{~S}$ production, nitrate reduction, urease activity and utilization of citrate as a sole carbon source. +, Positive; -, negative; w, weakly positive; ND, not determined/no data available.

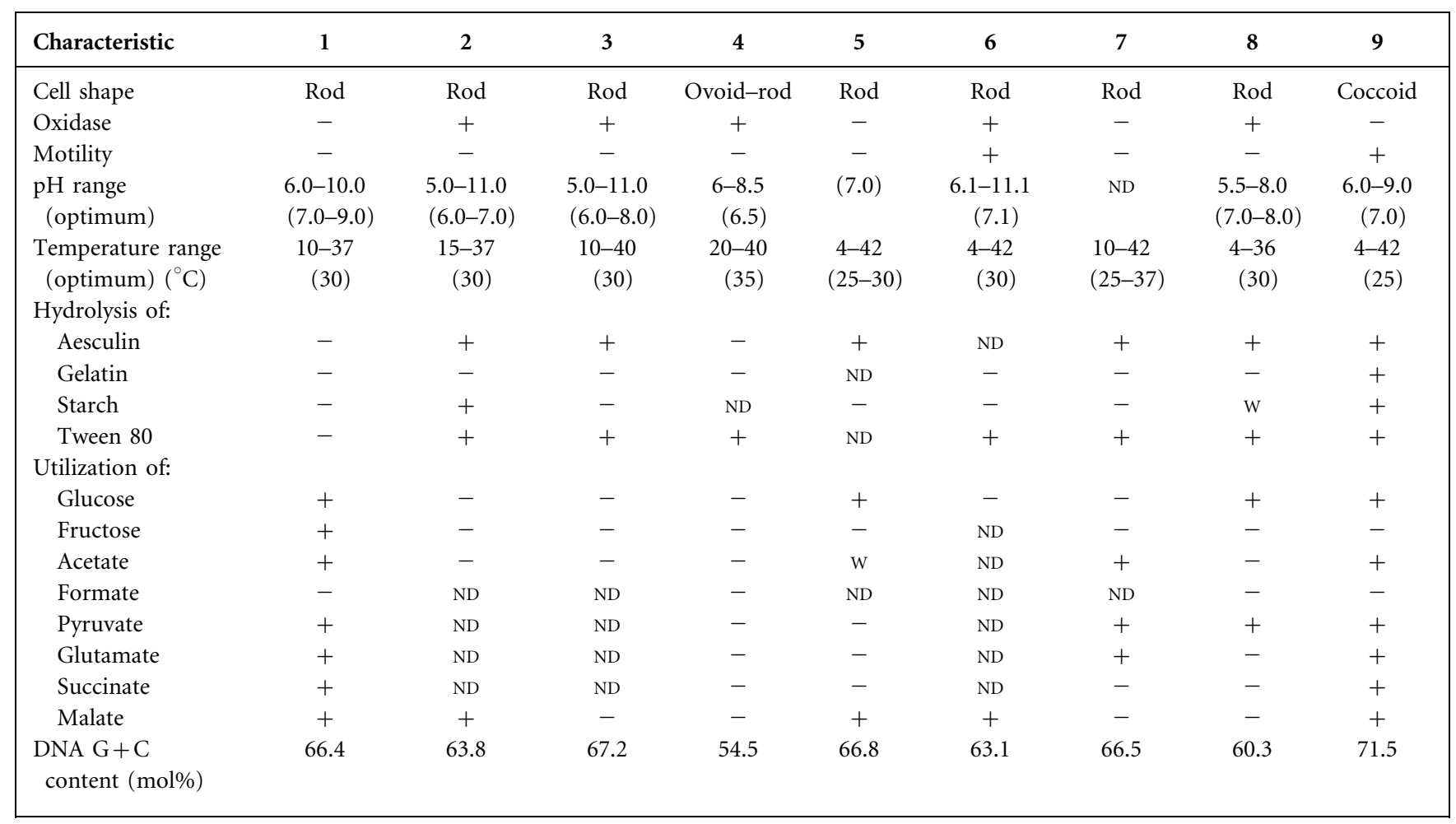




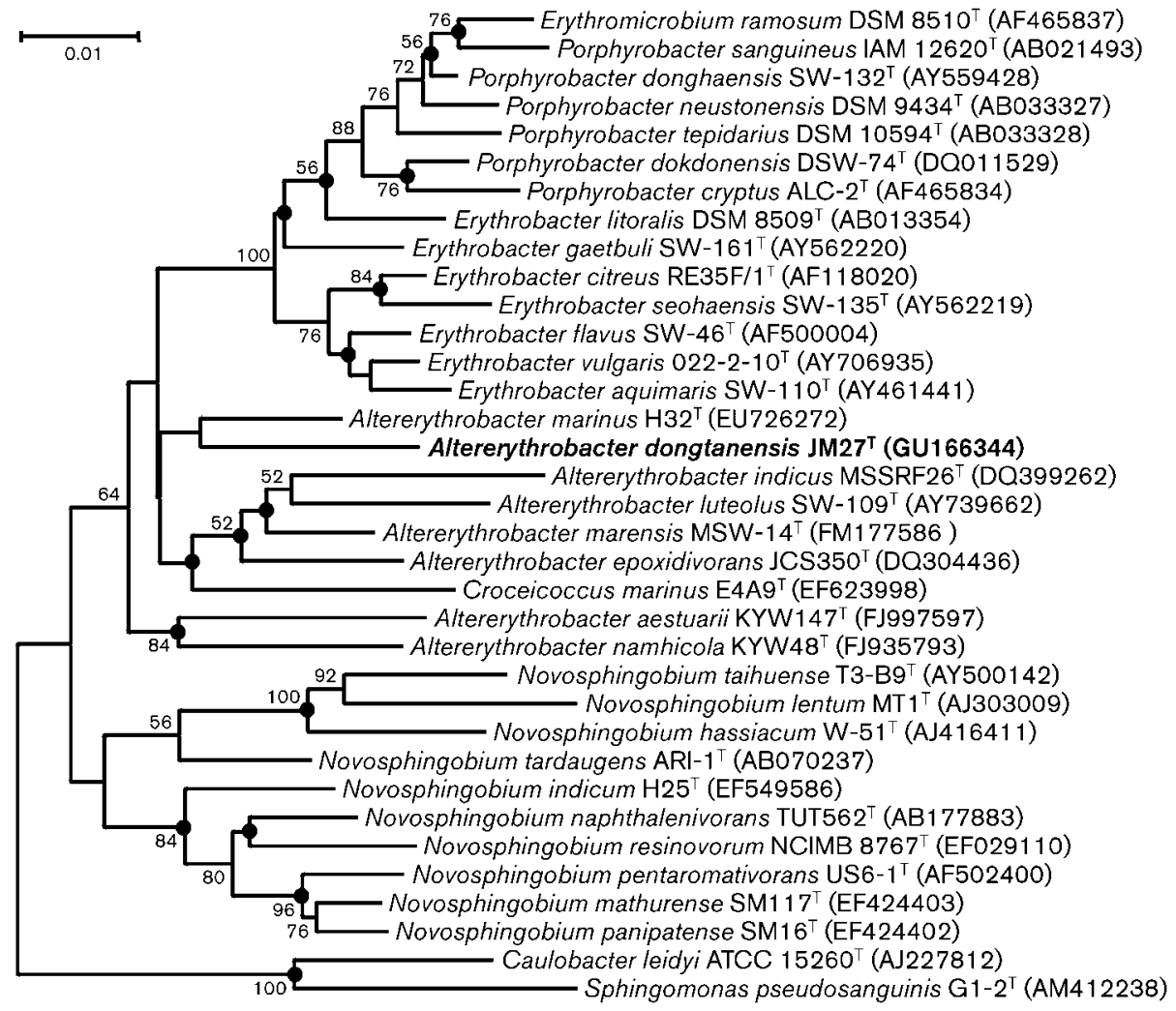

Fig. 1. Neighbour-joining phylogenetic tree based on 16S rRNA gene sequences showing the phylogenetic position of strain $\mathrm{JM} 27^{\top}$ within the family Erythrobacteraceae. Bootstrap values (expressed as percentages of 1000 replications) greater than 50 are shown at branching points. Filled circles indicate branches that were also recovered by using the maximum-parsimony algorithm. Bar, 1 substitution per 100 nt positions.

by the Microbial Identification software package (Sasser, 1990). Polar lipids were isolated by using standard procedures (Komagata \& Suzuki, 1987) and separated by TLC according to the method of Minnikin et al. (1984). The G + C content of the DNA was determined by the fluorescence monitoring method (Xu et al., 2000; Gonzalez \& Saiz-Jimenez, 2002) with a real-time thermal cycler (Mx3000p; Stratagene). Genomic DNA of Escherichia coli B (Sigma-Aldrich) and Pseudomonas aeruginosa KCTC $1750^{\mathrm{T}}$ was used as calibration references.

The major respiratory quinone was ubiquinone $10(\mathrm{Q} 10)$, as in all members of the genus Altererythrobacter. The fatty acid profile of strain $\mathrm{JM}^{2} 7^{\mathrm{T}}$ and other members of the genus Altererythrobacter are shown in Table 2. The major fatty acids were $\mathrm{C}_{18: 1} \omega 7 c(34.0 \%), \mathrm{C}_{17: 1} \omega 6 c$ $(19.8 \%)$ and $\mathrm{C}_{16: 0} 2-\mathrm{OH}(12.5 \%)$ with smaller amounts of $\mathrm{C}_{15: 0} 2-\mathrm{OH}(7.4 \%), \mathrm{C}_{16: 0}(7.1 \%)$, summed feature 3 (6.1\%, comprising $\mathrm{C}_{16: 1} \omega 7 c$ and/or iso- $\mathrm{C}_{15: 0} 2-\mathrm{OH}$ ), $\mathrm{C}_{14: 0} \quad 2-\mathrm{OH} \quad(5.6 \%), \quad \mathrm{C}_{16: 1} \omega 5 c \quad(2.8 \%), \quad 11$-methyl $\mathrm{C}_{18: 1} \omega 7 c(2.2 \%), \mathrm{C}_{18: 1} \quad 2-\mathrm{OH}(1.6 \%)$ and iso- $\mathrm{C}_{16: 0}$ $3-\mathrm{OH}(0.9 \%) \cdot \mathrm{C}_{18: 1} \omega 7 c$ is the most abundant fatty acid among members of the genus Altererythrobacter. Diphosphatidylglycerol, phosphatidylethanolamine and phosphatidylglycerol were the major polar lipids. These three polar lipids were also the major polar lipids in other species of the genus Altererythrobacter such as A. aestuarii (Park et al., 2011) and A. indicus (Kumar et al., 2008). The DNA G + C content of strain JM $27^{\mathrm{T}}$ was $66.4 \mathrm{~mol} \%$, which is similar to those of $A$. indicus MSSRF $26^{\mathrm{T}}$ (66.8 mol\%, Kumar et al., 2008), A. marinus $\mathrm{H} 32^{\mathrm{T}}$ (66.5 mol\%, Lai et al., 2009) and A. aestuarii KYW $147^{\mathrm{T}}$ (67.2 mol\%, Park et al., 2011).

On the basis of the phylogenetic tree, and biochemical and physiological characteristics, it is proposed that strain JM $27^{\mathrm{T}}$ belongs to the genus Altererythrobacter. Due to the large phylogenetic distance and different phenotypic characteristics of the new strain compared with those of the type strains of members of the genus Altererythrobacter, strain $\mathrm{JM} 27^{\mathrm{T}}$ should be classified as a novel species of the genus Altererythrobacter, for which the name Altererythrobacter dongtanensis sp. nov. is proposed.

\section{Description of Altererythrobacter dongtanensis sp. nov.}

Altererythrobacter dongtanensis (dong.ta.nen'sis. N.L. masc. adj. dongtanensis pertaining to Dongtan, a wetland region in Chongming Island, Shanghai, China). 
Table 2. Fatty acid patterns (\%) of strain $\mathrm{JM} 27^{\top}$ and the type strains of other species of the genus Altererythrobacter

Strains: $1, \mathrm{JM}_{2} 7^{\mathrm{T}}$ (data from this study); 2, A. namhicola $\mathrm{KYW} 48^{\mathrm{T}}$; 3, A. aestuarii $\mathrm{KYW} 147^{\mathrm{T}}$; 4, A. epoxidivorans $\mathrm{JCS} 350^{\mathrm{T}} ; 5$, A. indicus

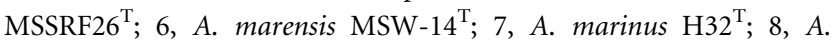
luteolus $\mathrm{SW}-109^{\mathrm{T}}$. Data for reference strains were taken from Park et al. (2011). All cells were grown on MA plates for 3 days at $30{ }^{\circ} \mathrm{C}$. - , Not detected.

\begin{tabular}{|c|c|c|c|c|c|c|c|c|}
\hline Fatty acid & 1 & 2 & 3 & 4 & 5 & 6 & 7 & 8 \\
\hline \multicolumn{9}{|l|}{ Straight-chain } \\
\hline $\mathrm{C}_{15: 0}$ & - & 3.2 & - & - & - & 0.8 & - & - \\
\hline$C_{16: 0}$ & 7.1 & 5.8 & 14.6 & 4.9 & 7.0 & 9.0 & 5.3 & 4.7 \\
\hline $\mathrm{C}_{18: 0}$ & - & - & - & - & 0.5 & - & - & - \\
\hline \multicolumn{9}{|l|}{ Unsaturated } \\
\hline $\mathrm{C}_{16: 1} \omega 5 c$ & 2.8 & - & - & 3.2 & - & 1.9 & 1.1 & 3.1 \\
\hline$C_{17: 1} \omega 6 c$ & 19.8 & 19.9 & 2.9 & 2.1 & 5.4 & 3.8 & 5.0 & 1.8 \\
\hline $\mathrm{C}_{17: 1} \omega 8 c$ & - & 2.1 & - & - & 1.2 & - & 0.7 & - \\
\hline $\mathrm{C}_{18: 1} \omega 5 c$ & - & - & - & 1.2 & 1.0 & - & 1.9 & 1.1 \\
\hline $\mathrm{C}_{18: 1} \omega 7 c$ & 34.0 & 35.2 & 36.1 & 42.6 & 63.6 & 40.4 & 48.8 & 41.7 \\
\hline $\mathrm{C}_{18: 1} \omega 9 c$ & - & - & 7.9 & - & - & - & - & - \\
\hline $\begin{array}{l}\text { 11-Methyl } \\
\mathrm{C}_{18: 1} \omega 7 c\end{array}$ & 2.2 & - & 11.0 & 6.0 & - & 18.1 & 23.7 & 5.0 \\
\hline \multicolumn{9}{|l|}{ Cyclic } \\
\hline $\mathrm{C}_{19: 0} \omega 8 c$ cyclo & - & - & - & - & - & - & 0.7 & - \\
\hline \multicolumn{9}{|l|}{ Hydroxy } \\
\hline $\mathrm{C}_{14: 0} 2-\mathrm{OH}$ & 5.6 & 7.5 & - & 3.7 & 13.8 & 5.7 & 3.2 & 3.9 \\
\hline $\mathrm{C}_{15: 0} 2-\mathrm{OH}$ & 7.4 & 3.5 & - & - & 1.2 & - & - & - \\
\hline $\mathrm{C}_{16: 0} 2-\mathrm{OH}$ & 12.5 & - & 9.0 & 2.1 & 0.8 & 3.0 & 1.8 & 2.1 \\
\hline $\mathrm{C}_{17: 0} 3-\mathrm{OH}$ & - & - & - & 3.2 & 4.5 & 5.4 & 2.7 & 5.3 \\
\hline iso- $\mathrm{C}_{16: 0} 3-\mathrm{OH}$ & 0.9 & - & - & - & - & - & - & - \\
\hline $\mathrm{C}_{16: 1} 2-\mathrm{OH}$ & - & - & - & 1.2 & - & - & - & 1.2 \\
\hline $\mathrm{C}_{18: 1} 2-\mathrm{OH}$ & 1.6 & - & - & - & - & - & - & - \\
\hline $\begin{array}{l}\text { Summed } \\
\text { feature } 3^{*}\end{array}$ & 6.1 & 22.7 & 18.4 & 29.8 & 1.1 & 12.7 & 4.6 & 29.1 \\
\hline
\end{tabular}

${ }^{\star}$ Summed feature 3 comprised $\mathrm{C}_{16: 1} \omega 7 c$ and/or iso- $\mathrm{C}_{15: 0} 2-\mathrm{OH}$.

Cells are Gram-negative, aerobic, non-spore-forming rods approximately $0.4-0.5 \times 0.5-1.1 \mu \mathrm{m}$ in size; no flagellum is detected. Visible yellow colonies are formed after 2 days of incubation at $30{ }^{\circ} \mathrm{C}$ on $\mathrm{R} 2 \mathrm{~A}$ agar. Colonies are smooth, circular and wet. Cells do not produce flexirubin-type pigment on R2A agar. Growth occurs between 10 and $37{ }^{\circ} \mathrm{C}$ (optimum $30-37{ }^{\circ} \mathrm{C}$ ), at $\mathrm{pH}$ 6.0-10.0 (optimum $\mathrm{pH} 7.0-9.0$ ) and in the presence of $0-1 \% \mathrm{NaCl}$ (optimum $0 \%)$. Positive for catalase and negative for oxidase. Positive for esterase (C4), esterase lipase (C8), naphthol-AS-BIphosphohydrolase and $\beta$-galactosidase, but negative for urease, leucine arylamidase, $\alpha$-glucosidase, $\beta$-glucosidase, lipase (C14), arginine dihydrolase, $\alpha$-chymotrypsin, $\alpha$ galactosidase, alkaline phosphatase, acid phosphatase, valine arylamidase, cystine arylamidase, $\beta$-glucuronidase, $\alpha$-fucosidase, $\alpha$-mannosidase and $N$-acetyl- $\beta$-glucosaminidase. Negative for acidification of D-glucose, production of indole and $\mathrm{H}_{2} \mathrm{~S}$, trypsin activity and hydrolysis of starch, aesculin, gelatin and Tween 80 . Nitrate and nitrite are not reduced under anaerobic conditions. The following substrates are not utilized as sole carbon source: caprate, adipate, arabinose, citrate, gluconate, maltose, mannitol, mannose, $\mathrm{N}$-acetylglucosamine or phenylacetate. The following substrates are utilized as sole carbon source: D-glucose, fructose, acetate, pyruvate, glutamate, succinate and malate. Ubiquinone 10 (Q10) is the major respiratory quinone. The major fatty acids are $\mathrm{C}_{18: 1} \omega 7 \mathrm{c}$, $\mathrm{C}_{17: 1} \omega 6 c$ and $\mathrm{C}_{16: 0}$ 2-OH. Diphosphatidylglycerol, phosphatidylethanolamine and phosphatidylglycerol are the major polar lipids. The DNA $\mathrm{G}+\mathrm{C}$ content of the type strain is $66.4 \mathrm{~mol} \%$.

The type strain, $\mathrm{JM} 27^{\mathrm{T}}\left(=\mathrm{KCTC} 22672^{\mathrm{T}}=\right.$ CCTCC AB $209199^{\mathrm{T}}$ ), was isolated from a tidal flat (Dongtan Wetland, Chongming Island, Shanghai, China).

\section{Acknowledgements}

This work was supported by National Key Technology R\&D Program of China (no. 2006BAJ05A11).

\section{References}

Chun, J., Lee, J.-H., Jung, Y., Kim, M., Kim, S., Kim, B. K. \& Lim, Y.-W. (2007). EzTaxon: a web-based tool for the identification of prokaryotes based on $16 \mathrm{~S}$ ribosomal RNA gene sequences. Int J Syst Evol Microbiol 57, 2259-2261.

Cowan, S. T. \& Steel, K. J. (1993). Manual for the Identification of Medical Bacteria, 3rd edn. Edited by G. I. Barrow \& R. K. A. Feltham. Cambridge: Cambridge University Press.

Fautz, E. \& Reichenbach, H. (1980). A simple test for flexirubin-type pigments. FEMS Microbiol Lett 8, 87-91.

Felsenstein, J. (1985). Confidence limits on phylogenies: an approach using the bootstrap. Evolution 39, 783-791.

Gerhardt, P., Murray, R. G. E., Wood, W. A. \& Krieg, N. R. (editors) (1994). Methods for General and Molecular Bacteriology. Washington, DC: American Society for Microbiology.

Gonzalez, J. M. \& Saiz-Jimenez, C. (2002). A fluorimetric method for the estimation of $\mathrm{G}+\mathrm{C} \mathrm{mol} \%$ content in microorganisms by thermal denaturation temperature. Environ Microbiol 4, 770-773.

Jukes, T. H. \& Cantor, C. R. (1969). Evolution of protein molecules. In Mammalian Protein Metabolism, pp. 21-132. Edited by H. N. Munro. New York: Academic Press.

Komagata, K. \& Suzuki, K. (1987). Lipid and cell-wall analysis in bacterial systematics. Methods Microbiol 19, 161-207.

Kumar, N. R., Nair, S., Langer, S., Busse, H.-J. \& Kämpfer, P. (2008). Altererythrobacter indicus sp. nov., isolated from wild rice (Porteresia coarctata Tateoka). Int J Syst Evol Microbiol 58, 839-844.

Kwon, K. K., Woo, J.-H., Yang, S.-H., Kang, J.-H., Kang, S. G., Kim, S.-J., Sato, T. \& Kato, C. (2007). Altererythrobacter epoxidivorans gen. nov., sp. nov., an epoxide hydrolase-active, mesophilic marine bacterium isolated from cold-seep sediment, and reclassification of Erythrobacter luteolus Yoon et al. 2005 as Altererythrobacter luteolus comb. nov. Int J Syst Evol Microbiol 57, 2207-2211.

Lai, Q. L., Yuan, J. \& Shao, Z. Z. (2009). Altererythrobacter marinus sp. nov., isolated from deep seawater. Int J Syst Evol Microbiol 59, 2973-2976.

MacFaddin, J. F. (1985). Media for Isolation-Cultivation-IdentificationMaintenance of Medical Bacteria, vol. 1. Baltimore: Williams \& Wilkins. 
Minnikin, D. E., O'Donnell, A. G., Goodfellow, M., Alderson, G., Athalye, M., Schaal, A. \& Parlett, J. H. (1984). An integrated procedure for the extraction of bacterial isoprenoid quinones and polar lipids. J Microbiol Methods 2, 233-241.

Park, S. C., Baik, K. S., Choe, H. N., Lim, C. H., Kim, H. J., Ka, J. O. \& Seong, C. N. (2011). Altererythrobacter namhicola sp. nov. and Altererythrobacter aestuarii sp. nov., isolated from seawater. Int J Syst Evol Microbiol 61, 709-715.

Quan, Z. X., Bae, H. S., Baek, J. H., Chen, W. F., Im, W. T. \& Lee, S. T. (2005). Rhizobium daejeonense sp. nov. isolated from a cyanide treatment bioreactor. Int J Syst Evol Microbiol 55, 2543-2549.

Saitou, N. \& Nei, M. (1987). The neighbor-joining method: a new method for reconstructing phylogenetic trees. Mol Biol Evol 4, 406-425.

Sasser, M. (1990). Identification of bacteria by gas chromatography of cellular fatty acids, MIDI Technical Note 101. Newark, DE: MIDI Inc.

Seo, S. H. \& Lee, S. D. (2010). Altererythrobacter marensis sp. nov., isolated from seawater. Int J Syst Evol Microbiol 60, 307-311.

Stackebrandt, E. \& Goebel, B. M. (1994). Taxonomic note: a place for DNA-DNA reassociation and $16 \mathrm{~S}$ rRNA sequence analysis in the present species definition in bacteriology. Int J Syst Bacteriol 44, 846-849.
Swofford, D. L. (1993). PAUP. Phylogenetic analysis using parsimony, version 3.1.1. Champaign, IL: Illinois Natural History Survey.

Tamura, K., Dudley, J., Nei, M. \& Kumar, S. (2007). MEGA4: molecular evolutionary genetics analysis (MEGA) software version 4.0. Mol Biol Evol 24, 1596-1599.

Thompson, J. D., Gibson, T. J., Plewniak, F., Jeanmougin, F. \& Higgins, D. G. (1997). The CLUSTAL_X windows interface: flexible strategies for multiple sequence alignment aided by quality analysis tools. Nucleic Acids Res 25, 4876-4882.

Xu, H.-X., Kawamura, Y., Li, N., Zhao, L., Li, T.-M., Li, Z.-Y., Shu, S. \& Ezaki, T. (2000). A rapid method for determining the $\mathrm{G}+\mathrm{C}$ content of bacterial chromosomes by monitoring fluorescence intensity during DNA denaturation in a capillary tube. Int $J$ Syst Evol Microbiol 50, 1463-1469.

Xu, X.-W., Wu, Y.-H., Wang, C.-S., Wang, X.-G., Oren, A. \& Wu, M. (2009). Croceicoccus marinus gen. nov., sp. nov., a yellow-pigmented bacterium from deep-sea sediment, and emended description of the family Erythrobacteraceae. Int J Syst Evol Microbiol 59, 2247-2253.

Yoon, J.-H., Kang, K. H., Yeo, S.-H. \& Oh, T.-K. (2005). Erythrobacter luteolus sp. nov., isolated from a tidal flat of the Yellow Sea in Korea. Int J Syst Evol Microbiol 55, 1167-1170. 